\title{
MODELE SZKOLNEJ EDUKACJI MORALNEJ WOBEC ROZWOJU KOMPETENCJI MORALNYCH. ANALIZA PORÓWNAWCZA
}

\begin{abstract}
Chomczyńska-Rubacha Mariola, Rubacha Krzysztof, Modele szkolnej edukacji moralnej wobec rozwoju kompetencji moralnych. Analiza porównawcza [Models School Moral Education to the Development of Moral Competence. Comparative Analysis]. Studia Edukacyjne nr 42, 2016, Poznań 2016, pp. 7-28. Adam Mickiewicz University Press. ISSN 1233-6688. DOI: 10.14746/se.2016.42.1

The present text is a comparative analysis of models of school moral education due to the criteria of the moral competence development. We refer to the already described in the literature models: clarification of values, stimulate moral reasoning, formation of character and community justice. These models will be confronted with moral competence, which we understand as a system of knowledge of the values, skills, moral activities and taking responsibility for their actions. Results of the analysis showed that the model of community justice best meets with the criteria of moral competences.
\end{abstract}

Key words: moral education, moral competence, models of moral education

Prezentowany tekst stanowi analizę porównawczą modeli szkolnej edukacji moralnej ze względu na kryteria rozwijania kompetencji moralnych. Odwołujemy się do opisywanych już w literaturze modeli: klaryfikacji wartości, stymulowania rozumowania moralnego, kształtowania charakteru i wspólnoty sprawiedliwościowej. Modele te zostaną skonfrontowane z kompetencjami moralnymi, które rozumiemy jako układ wiedzy o wartościach, umiejętności działania moralnego oraz przyjmowania odpowiedzialności za swoje działania. Budując katalog kompetencji moralnych (kryteriów analizy porównawczej), oparliśmy się na rozwojowej konceptualizacji celu edukacji moralnej. Oznacza to, że piszemy o kompetencjach koniecznych do osiągania autonomii moralnej, czyli najwyższego stadium rozwoju moralne- 
go jednostki. Trzymanie się standardu rozwojowego w edukacji moralnej oznacza, że zmierza ona do rozwijania kompetencji pozwalających na podejmowanie dojrzałych decyzji i działań moralnych.

\section{Modele szkolnej edukacji moralnej. Klaryfikacja wartości}

Opis podejścia. Klaryfikacja wartości reprezentuje niedyrektywne, skupione głównie na afektywnym wymiarze życia moralnego, podejście do edukacji moralnej. W programach klaryfikacji wartości uczniowie zachęcani są do odkrywania własnych, a nie do przyjęcia arbitralnie wybranych wartości. Rolą nauczyciela jest jedynie towarzyszenie dziecku w jego samodzielnych aksjologicznych poszukiwaniach oraz pokazywanie możliwości, wolnych od ich oceny, krytyki, moralizowania i indoktrynacji. Podejście to zakłada otwartość, tolerancję oraz neutralność aksjologiczną nauczyciela po to, by wychowanek miał okazję odkryć własne wartości. W tym celu posługuje się następującymi metodami: wyjaśnianie uczniowi, że odwołał się do konkretnej wartości, dyskusje na temat wartości, zadania pisemne dotyczące wartości (np. ocena jakiegoś zachowania) ${ }^{1}$. Wykorzystuje się również dylematy moralne, prosząc uczniów o scharakteryzowanie własnego zachowania w opisanych sytuacjach i generowanie alternatywnych możliwości. Niekiedy uczniowie proszeni są o przedstawienie za pomocą różnych scenek dramatycznych swoich przekonań i wierzeń, dzięki czemu uświadamiają sobie własne preferencje $\mathrm{w}$ działaniu.

Podejście to, którego reprezentantami są Raths, Harmin i Simon, stawia sobie za cel uświadomienie uczniom znaczenia wartości w codziennym życiu. Autorzy programów klaryfikacji wartości podkreślają znaczenie doświadczania wartościowania jako procesu, a nie traktowania wartości w sposób instrumentalny. Proces wartościowania obejmuje wybieranie, ocenianie i działanie. Wybór wartości bazuje na rozpatrywaniu alternatyw. Ocenianie angażuje publiczne zatwierdzenie wartości. Działanie obejmuje zachowanie zgodne $\mathrm{z}$ wartościami².

Podstawy teoretyczne. Ojcem podejścia psychodynamicznego jest Zygmunt Freud, który jako pierwszy stworzył kompletną teorię wyjaśniającą

${ }_{1}$ Por. http://eguilibrio.blogi.com/czy-potrzebna-jest -nam-edukacja-moralna/9.08.2016.

2 S.B. Simon, R.C. Havley, D.D. Britton, Krystalizacja wartości. Ćwiczenia pisemne dla rozwoju osobowego, Torun - Poznań 1992; P.S. Kaplan, Educational psychology for tomorrow`s teacher, St. Paul - New York - Los Angeles - San Francisco 1990. 
proces internalizacji wartości moralnych. Podejście to kładzie nacisk na dynamiczne siły rządzące osobowością, będące głównym źródłem psychologicznych problemów. Według teorii psychodynamicznej, pierwotne motywy ludzkiego działania leżą we wrodzonych, nieświadomych strukturach osobowości (id). Id jest amoralne (działa według zasady przyjemności), irracjonalne, impulsywne i nie zwraca uwagi na ograniczenia społeczne. Tworzona w nim energia psychiczna usiłuje przedostać się do ego, ponieważ tylko ego ma możliwość kontaktowania się z otoczeniem i decydowania o zewnętrznej aktywności organizmu. Ego działa według zasady rzeczywistości; jego główną funkcją jest utrzymanie równowagi między zakazami i ograniczeniami płynącymi z otoczenia a popędami pochodzącymi z id. Wrodzone popędy napotykają jednak na drodze do ego cenzurę społeczeństwa, która zatrzymuje niektóre popędy. Uwewnętrznione zasady postępowania otoczenia tworzą warstwę osobowości zwaną superego. Odpowiadające sumieniu superego zawiera wewnętrzne reprezentacje wszystkich moralnych sankcji i zakazów, jakie istnieją w kulturze otaczającej jednostkę. Pogwałcenie tych często nierealistycznie wysokich standardów prowadzi do przeżywania przez jednostkę poczucia winy i lęku. Okazuje się zatem, że osobowość człowieka jest skonfliktowana w sposób nieunikniony: nigdy bowiem nie będzie tak, że społeczeństwo (a więc superego) pozwoli na realizację wszystkich popędów z id. Jednocześnie, wszystkie odrzucone przez superego treści nie są unicestwiane, lecz domagają się gratyfikacji (zaspokojenia) z coraz większą siłą (stąd nazwa: dynamika osobowości). Aparat psychiczny musi więc inwestować coraz większą ilość energii na trzymanie niedozwolonych motywów na uwięzi. Aby nie dopuścić do dezintegracji osobowości, uruchamiane są mechanizmy obronne, które są w stanie zmodyfikować nieodpowiednie treści tak, aby cenzura superego mogła je zaakceptować.

\section{Stymulowanie rozumowania moralnego}

Opis podejścia. Podejście to reprezentuje niedyrektywny model wychowania moralnego i skupia się głównie na doskonaleniu dyspozycji kognitywnych uczniów: moralnego rozumowania, ważenia argumentów i kontrargumentów, wyprowadzania wniosków z moralnych przesłanek. Celem edukacji moralnej jest więc stymulowanie procesów intelektualnych, które pozwolą uczniom samodzielnie dochodzić do moralnych przekonań, doskonalić techniki moralnego rozumowania i selekcjonowania wartości. Podejście to opracowane przez Kohlberga i Blatta wykorzystuje do tego celu dyskusję nad dylematami moralnymi. Dylemat jest przedstawiany klasie 
$\mathrm{w}$ formie opowiadania. Zadaniem uczniów jest przedstawienie argumentów na rzecz jego rozwiązania. $W$ toku dyskusji grupowej, analizując różne argumenty i kontrargumenty, uczniowie powinni dojść do własnego przekonania na temat najlepszego rozstrzygnięcia konkretnego dylematu. Stopień trudności dylematów należy dostosować do możliwości dzieci. Procedura ta zachęca do uwzględniania perspektyw wszystkich zaangażowanych stron, uzasadniania racji i ważenia skutków decyzji. Zgodnie z założeniami Kohlberga, uczniowie znajdujący się na niższym stadium rozumowania moralnego stykając się z rozumowaniem uczniów z wyższego stadium doświadczą konfliktu poznawczego, co może spowodować korzystne zmiany w ich rozumowaniu. Normalnie, przechodzenie $\mathrm{z}$ jednego stadium do następnego zajmuje kilka lat, w wyniku odpowiedniej interwencji wychowawczej można ograniczyć ten czas do 12-15 cotygodniowych spotkań.

Nauczyciel w tym podejściu nie podaje żadnych wyraźnych wskazówek, które rozstrzygnięcie jest moralnie słuszne, choć na zasadzie uczestnika dyskusji może wyrażać własne przekonania. Jedynie moderuje wymianę argumentów oraz koryguje od strony formalnej poprawność wykorzystanych $w$ dyskusji rozumowań. Mamy tu zatem do czynienia z pożądanym typem rozumowania, nie zaś z pożądanym typem odpowiedzi. Nie oznacza to, że Kohlberg jest moralnie neutralny. Wierzy w istnienie uniwersalnych zasad moralnych, takich jak szacunek dla jednostki, tolerancja, równość, ale równocześnie sądzi, że zasady te są możliwe do odkrycia dzięki racjonalnym argumentom i przemyślanym decyzjom odnośnie wartości, które mogą pozostawać ze sobą w konflikcie.

Podstawy teoretyczne. Poznawczo-rozwojowy model rozwoju moralnego bazuje na pracach Piageta i Kohlberga. Piaget uważał, że moralne i społeczne funkcjonowanie dziecka jest ściśle związane z poziomem jego rozwoju poznawczego. Po przeanalizowaniu odpowiedzi dzieci reprezentujących różne stadia rozwoju poznawczego wyróżnił dwa stadia $\mathrm{w}$ rozwoju myślenia moralnego: stadium moralności heteronomicznej (albo realizmu moralnego) oraz stadium moralności autonomicznej (inaczej relatywizmu moralnego). W stadium moralności heteronomicznej dziecko trzyma się zasad w sposób sztywny i interpretuje czyn ze względu na jego materialne konsekwencje, a nie intencje osoby, która się go dopuściła. W stadium relatywizmu moralnego reguły są traktowane jako efekt negocjacji i umowy społecznej, a sądy moralne uwzględniają zarówno intencje, jak i materialne konsekwencje czynu.

Kohlberg rozwijając prace Piageta, rozbudował jego model. Wyróżnił trzy poziomy rozwojowe (moralność przedkonwencjonalna, konwencjonal- 
na i postkonwencjonalna), z których każdy obejmuje dwa oddzielne stadia. Kohlberg uważa, że stadia te są stałe i każdy człowiek przechodzi przez nie w rozwoju w tej samej kolejności, poczynając od poziomu najniższego. Rezultatem finalnym rozwoju jest dojrzałe poczucie sprawiedliwości.

\section{Kształcenie charakteru}

Opis podejścia. Wychowanie moralne $\mathrm{w}$ duchu etyki cnót skupia się na pytaniu: "Jakiego rodzaju cechy charakteru powinien uosabiać wychowanek"? Cnoty etyczne rozumiane są jako nabyte i względnie trwałe kognitywno-afektywne dyspozycje do moralnie dobrego działania ${ }^{3}$. Wprowadza się tu rozróżnienie między behawioralnie rozumianą cnotą (jako zespołu automatycznych nawyków aktywizujących się niezależnie od okoliczności) a kognitywno-afektywnym ujęciem cnoty. W tym drugim przypadku kognitywny aspekt cnoty obejmuje wiedzę na temat dobra, rozpoznanie sytuacji moralnej i odpowiada za właściwe stosowanie zasad wyprowadzonych z treści pojęć poszczególnych cnót w konkretnych sytuacjach moralnych. Aspekt afektywny odnosi się do motywacyjnego charakteru emocji w kontekście zachowania moralnego. Przy takim kognitywno-afektywnym ujęciu cnoty etycznej zasady wynikające z poszczególnych cnót - prawdomówności, cierpliwości, gotowości do pomocy, życzliwości - wyznaczają jedynie kierunki działania, a nie z konieczności ustalony ich przebieg4.

Koncepcja wychowania moralnego przez kształtowanie cnót etycznych ma charakter dyrektywny. Oznacza to dawanie wychowankom wyraźnych wskazówek na temat moralnie dobrych i złych postaw oraz działań, zwłaszcza na wcześniejszych etapach rozwoju dziecka. W kognitywno-afektywnym ujęciu cnoty proces edukacyjny wykracza poza trenowanie określonego zachowania czy nawyków. Oznacza dostarczanie doświadczeń służących rozwojowi percepcji moralnej (zdolności do dostrzegania mających moralne znaczenie sytuacji, relacji, doświadczeń), wrażliwości moralnej (zdolność do odczytywania potrzeb, oczekiwań i interesów innych osób oraz liczenie się z nimi na równi z własnymi) oraz wyobraźni moralnej (zdolność wczuwania się w sytuację innych ludzi jako adresatów działania). W wymiarze afektywnym praca nad doskonaleniem charakteru koncentruje się na wzbudzaniu motywacji do samodoskonalenia i moralnie dobrego działania. $W$ tym celu wykorzystuje się autorytety moralne, literaturę, filmy itp. Zdaniem

\footnotetext{
${ }^{3}$ Por. N. Szutta, Wychowanie moralne z perspektywy etyki cnót, Diametros, 2015, 46, s. 113.

${ }^{4}$ Za: tamże, s. 115.
} 
Ryana ${ }^{5}$, program budowania charakteru wymaga spełnienia pięciu warunków: operowania przykładami, posługiwania się wyjaśnieniami, stosowania oddziaływań perswazyjnych, kreowania środowiska moralnego i dostarczania uczniom doświadczeń moralnych.

Argumentowanie, że szkoła ponosi odpowiedzialność za kształtowanie charakteru, uczenie moralności oraz transmisję wartości i porządku aksjologicznego społeczeństwa pozostawia otwartą kwestię doboru wartości. W wielokulturowym i pluralistycznym społeczeństwie ich wybór nie jest oczywisty. Jesteśmy świadkami renesansu tradycyjnych wartości jako odpowiedzi na obwieszczony przez konserwatystów kryzys wartości, będący pochodną kryzysu współczesnej młodzieży, kultury i społeczeństwa. I tak, większość tradycyjnych podejść do edukacji charakteru podkreśla rolę nawyku, naśladownictwa, modelowania, instrukcji, nagród i kar oraz autorytetu $\mathrm{w}$ formowaniu charakteru. Przez opozycjonistów zwrot ten interpretowany jest jako represyjny i skoncentrowany na nauczycielu. Pozostaje on w wyraźnym konflikcie z rzecznikami podejść skoncentrowanych na dziec$\mathrm{ku}$ i podkreślających rolę rozwoju moralnego będącego efektem racjonalnej deliberacji6. Inne pole konfliktu stanowią wartości konserwatywne skupione wokół filarów charakteru odnoszących się do etyki cnót (solidność, bycie godnym zaufania, szacunek, odpowiedzialność, sprawiedliwość, uczciwość, aktywność obywatelska) versus wartości lewicowe podnoszące kwestie społecznej niesprawiedliwości, takie jak rasizm czy dyskryminacja płciowa. Badacze zorientowani lewicowo interpretują renesans tradycyjnych wartości jako reakcję na zadomowienie się wartości równościowych ${ }^{7}$. Podobny zwrot obserwujemy też w Polsce. Narodowy Program Wychowania - jak sama nazwa wskazuje - ma stać na straży wartości narodowo-katolickich (Bóg, honor, ojczyzna).

Problem konfliktowych wartości zwolennicy dyrektywnego modelu wychowania moralnego rozwiązują poszukując wartości, wokół których udaje się zbudować konsensus. Generalnie istnieje zgoda co do takich wartości, jak np. lojalność, odpowiedzialność, obowiązkowość. Listę tę można uzupełnić o wartości leżące u podstaw systemu demokratycznego, takie jak wolność, równość, braterstwo, tolerancja.

Podstawy teoretyczne. Reprezentanci teorii społecznego uczenia się (Bandura) próbując wyjaśnić moralne zachowanie, odwołują się do zdolno-

${ }^{5}$ Za: P.S. Kaplan, Educational psychology.

6 Por. J. Arthur, Traditional approaches to character education in Britain and America, [w:] Handbook of moral and character education, red. L.P. Nucci, D. Narvaez, New York 2008, s. 80.

7 L.P. Nucci, D. Narvaez, Introduction and overview, [w:] tamże, s. 1. 
ści jednostki do moralnego zachowania oraz do zaniechania łamania reguł moralnych, gdy istnieje taka pokusa. Teoria ta zakłada, że moralność jest wynikiem uczenia się, szczególnie poprzez modelowanie i warunkowanie. Prace Bandury nad uczeniem się przez obserwację wykazały, że obserwowanie przez dziecko modela, który jest karany za niemoralne zachowanie sprawia, że dziecko doświadcza kary pośredniej, powodującej unikanie tego zachowania. Dziecko może stać się moralne lub niemoralne w zależności od tego, w jakich warunkach się wychowuje i jakich wzorców dostarczą mu rodzice oraz inne osoby znaczące. Zachowanie dziecka jest początkowo kontrolowane za pomocą rodzicielskich kar i nagród. Rezultatem doznawania kary w sytuacjach łamania reguł jest lęk. W późniejszym okresie zachowanie moralne jest efektem samokontroli aktywizowanej przez skojarzenie lęku z łamaniem reguł. Postępowanie według tej koncepcji to zachowanie konformistyczne podporządkowane normom oraz autorytetom uznawanym w danej społeczności, pozostające pod kontrolą sankcji i mechanizmów samokontroli.

\section{Wspólnota sprawiedliwościowa}

Opis podejścia. Podejście określane jako wspólnota sprawiedliwościowa, reprezentowane przez Kohlberga i współpracowników (Power, Higgins), promuje rozwój moralny i odpowiedzialność moralną poprzez organizację i kulturę samej szkoły. Skupia się na praktykach życia codziennego, normach, wartościach, procesie podejmowania decyzji oraz systemie nagród i kar, które wpływają na szkolne życie i dyscyplinę. W celu zredukowania wpływu ukrytego programu szkoły większość decyzji dotyczących codziennego życia i dyscypliny podejmowana jest demokratycznie na obowiązkowych cotygodniowych zebraniach całej społeczności, w trakcie których uczniowie i nauczyciele mają równe prawo głosu. Godziny wychowawcze w klasach są wykorzystywane do przygotowania się do tych zebrań. Celem tych działań jest wypracowanie modelu życia moralnego ukierunkowanego na etykę sprawiedliwości i budowanie solidarności grupy. Nauczyciele pełnią rolę liderów, stojąc na straży ideałów społeczności i wspierając zaangażowanie uczniów.

Od początku podejście to miało stanowić pomost pomiędzy stymulowaniem rozumowania moralnego a działaniem moralnym. Spotkania społeczności (szkolnej, klasowych) stymulują wrażliwość moralną. Wiele kwestii, takich jak agresja, kradzieże, oszustwa, prześladowanie, opuszczanie zajęć, zażywanie narkotyków, picie alkoholu należy do dziedziny moralności 
i mogą stać się przedmiotem dyskusji oraz znajdowania rozwiązań problemów służących wspólnemu dobru. Wspólnota sprawiedliwościowa wymusza wysokie standardy we wzajemnych relacjach i troskę o całą społeczność. Poprzez wspólne rozwiązywanie realnych problemów, wypracowanie reguł życia codziennego uczy podejmowania decyzji moralnych, sprzyja braniu odpowiedzialności za siebie i innych i ułatwia identyfikację ze społecznością oraz jej wartościami moralnymi. Kiedy dochodzi do zachowania niezgodnego z przyjętymi wartościami, cała społeczność zastanawia się, jak można lepiej realizować ideały. Oznacza to, że moralna kultura szkoły ulega ciągłej transformacji, a za jej pośrednictwem transformacji podlegają też jej członkowie ${ }^{8}$.

Wspólnota sprawiedliwościowa stanowi swoiste laboratorium demokracji. Zakłada partycypację w stanowieniu praw i reguł oraz obywatelską odpowiedzialność. Podejście to ma dwa równorzędne cele: stymulować rozwój moralny uczniów i przekształcić atmosferę szkoły w społeczność kierującą się wartościami moralnymi.

Podstawy teoretyczne. Podejście to wykorzystuje wyniki badań nad rozwojem moralnym Piageta i Durkheima. Piaget opisał dwa typy moralności: moralność heteronomiczną charakteryzującą się niekwestionowanym posłuszeństwem wobec narzuconych zasad i autorytetów oraz moralność autonomiczną, kiedy reguły traktowane są jako efekt negocjacji i umowy społecznej. Piaget podkreślał związek pomiędzy dziecięcymi sądami moralnymi a społecznym kontekstem. Wyrażał sceptycyzm wobec wpływu szkoły na rozwój moralny. Obawiał się, że szkoła podtrzymuje i utwierdza dzieci w konformizmie wobec norm klasowych oraz oczekiwań nauczycieli. Zakładał jednak, że nauczyciele mogą być bardziej egalitarni. Rozwijając idee Deweya wierzył, że demokratyczne środowisko mogłoby dać dzieciom moralną wolność potrzebną do rozwoju poznawczego i moralnego.

Durhheim stał na stanowisku, że skuteczna edukacja moralna wymaga zaangażowania uczniów w budowę zintegrowanej grupy kierującej się zasadami oraz duchem samopoświęcenia i altruizmu. Podstawowym zadaniem edukacji moralnej według Durheima jest przekierowanie zainteresowania własnym ja uczniów na troskę o grupę jako całość.

Kolejne podejście inspiracje określane jako wspólnota sprawiedliwościowa czerpie z krytyki wczesnych teorii Kohlberga dotyczących rozwoju moralnego. Carol Gilligan, uczennica i długoletnia współpracownica Kohl-

8 F.C. Power, A. Higgins-D`Alessandro, The just community approach to moral education and the moral atmosphere of the school, [w:] tamże. 
berga, zasugerowała, że nie uwzględnia ona specyfiki rozumowania moralnego kobiet. Jej zdaniem, należy wyróżnić dwie orientacje moralne czy koncepcje etyczne, które charakteryzują rozumowanie moralne kobiet i mężczyzn. Pierwsza z nich to opisana przez Kohlberga etyka sprawiedliwości, druga to etyka troski i odpowiedzialności. Ta druga akcentuje odpowiedzialność i zobowiązanie człowieka wobec bliźnich. Rozróżnienie to odnosi się do sposobu, w jaki jednostka rozważa problemy moralne. Perspektywa sprawiedliwości oznacza nacisk na wzajemność, równość i szacunek, podczas gdy dla perspektywy troski charakterystyczna jest troska, opieka i otwartość na potrzeby innych. Kohlberg zaadaptował wnioski płynące $\mathrm{z}$ tej krytyki do swojej koncepcji wspólnoty sprawiedliwościowej. Wspólnota powstaje jako wynik akceptacji współodpowiedzialności za budowanie stosunków wewnątrzgrupowych charakteryzujących się wzajemną troską, zaufaniem i zbiorową odpowiedzialnością za dobro jednostek i wspólnoty. Termin wspólnota sprawiedliwościowa akcentuje zatem dwa elementy: troskę we wzajemnych relacjach oraz wolność, równość i szacunek w zbiorowym podejmowaniu decyzji ${ }^{9}$.

\section{Kompetencje społeczno-moralne}

Analiza edukacji pogłębiającej zdolności człowieka do dojrzałego moralnie działania wymaga odwołania się do języka opisu jej celów i zadań. Dokonać tego można na różnych poziomach ogólności. Najwyższy poziom odwołuje się do katalogu wartości, które są zaangażowane w konstrukcje ideałów wychowania (cele naczelne). Uwzględniają one określony kontekst historyczny i społeczny oraz stan refleksji filozoficznej i nauki, ideologii, polityki oraz warunków życia i potrzeb społeczeństwa (inne będą w warunkach stabilizacji, a inne w czasach kryzysu). Przyjęcie określonego systemu wartości, a zwłaszcza określenie wartości naczelnych różnicuje w największym stopniu ideały wychowania. Drugi poziom analizy dotyczy formalnych i treściowych składników celów edukacji moralnej (cele ogólne i etapowe). W jego efekcie powstaje katalog dyspozycji osobowościowych, nawyków, postaw itp. zrelatywizowanych do warunków ich realizacji na poszczególnych etapach kształcenia ${ }^{10}$. Trzeci poziom analizy charakteryzuje odwołanie się do języka obserwowalnych efektów edukacji, wyrażonych w postaci kompetencji społeczno-moralnych (cele operacyjne). Zajmowanie

9 Tamże.

${ }^{10}$ Por. K. Konarzewski, Pedagogika celów czy pedagogika wartości? Kwartalnik Pedagogiczny, 2013, 2. 
się kompetencjami społeczno-moralnymi jest odpowiedzią na żądanie przygotowania młodych ludzi do życia w świecie, którego kształtu nie możemy przewidzieć.

Potencjalnie każdy z tych języków opisu celów i zadań może profilować edukację moralną. Jednostronny nacisk na wartości wydaje się jednak działaniem wąskim, ale także skierowanym na obszar, który raczej nie wymaga ingerencji. Pisał o tym De Waal, przywołując wyniki badań potwierdzające, że takie wartości jak wzajemność, sprawiedliwość, wdzięczność, troska o wspólnotę regulowały już życie przodków człowieka i zostały zapisane $\mathrm{w}$ materiale genetycznym jako gatunkowe presje na przetrwanie ${ }^{11}$. Lind również uważa, że uczenie wartości nie może być celem edukacji moralnej, zwłaszcza że zgodnie z allportowską zasadą "pluralistycznej ignorancji”, bez względu na to jakie wartości ludzie wyznają, uważają, że inni ich nie wyznają. Zakładają, że jeśli oczekiwaliby od innych określonego zachowania, ono się nie pojawi ${ }^{12}$. W tej sytuacji należałoby się skupić na korygowaniu zniekształconego postrzegania moralności innych, zamiast prezentować dzieciom i młodzieży kolejne katalogi wartości. One bowiem nie zmienią zasady "pluralistycznej ignorancji”, która ostatecznie powstrzymuje ludzi przed etyczną otwartością na innych.

Podobnie nie wydaje się, by edukacja moralna miała się zbyt silnie koncentrować na kształtowaniu cech osobowości, postaw i nawyków moralnie poprawnych, ponieważ nie można z góry przewidzieć, jaka decyzja moralna będzie najlepsza $\mathrm{w}$ potencjalnie niepoliczalnej ilości sytuacji konfliktowych $^{13}$. Sztywność schematycznych scenariuszy właściwego zachowania się jest nieadekwatna do złożoności codziennych sytuacji wymagających podejmowania decyzji moralnych. Jeśli zatem ideały (wartości) moralne ani gotowe wzorce zachowania nie idą $\mathrm{w}$ parze $\mathrm{z}$ dojrzałym moralnie działaniem, to edukacja moralna powinna się skupić na kompetencjach diagnozowania sytuacji konfliktowych, oceniania jakie wartości pomogą je rozwiązać i działania zgodnego z tymi wartościami. Wydaje się więc, że model edukacji skupionej na kompetencjach społeczno-moralnych jest $\mathrm{w}$ stanie zbudować most między deklarowanymi wartościami a działaniem w sytuacjach wymagających ich zastosowania. Kompetencje stają się wówczas narzędziem do moralnej orientacji $\mathrm{w}$ świecie i podejmowania przemyślanych, moralnie uzasadnionych decyzji. Tym samym, $\mathrm{w}$ miejsce gotowych rozwiązań czy abstrakcyjnych wartości oferują narzędzie regulacji stosunków jednostki z otoczeniem społecznym.

${ }^{11}$ F. De Waal, Małpy i filozofowie, przekł. B. Brożek, M. Furman, Kraków 2013, s. 67-85.

${ }^{12}$ G. Lind, Edukacja moralna. Teoria dwuaspektowa, Principia, 2013, LVII-LVIII, s. 44.

13 Tamże, s. 43. 
Czym są kompetencje moralne? Kompetencje społeczno-moralne obejmują zakres czyjejś wiedzy, umiejętności i odpowiedzialności. Nie należy ich zatem redukować do żadnego z tych składników. Kompetencji społeczno-moralnych nie można zatem utożsamiać z abstrakcyjnie pojętymi wartościami czy znajomością etycznych koncepcji. Nie są też substytutem umiejętności, czyli algorytmów działania w określonych sytuacjach. Mieć kompetencje $\mathrm{w}$ jakiejś dziedzinie oznacza zdolność podejmowania racjonalnych, odpowiedzialnych decyzji opartych na posiadanej wiedzy i umiejętnościach. W tak rozumianych kompetencjach społeczno-moralnych wyróżnić można trzy składniki: kompetencje poznawczo-moralne, kompetencje sądzenia moralnego, kompetencje projektowania działania moralnego ${ }^{14}$. W obrębie każdej z trzech grup wyróżnić można komponenty bardziej szczegółowe, które stanowią też rodzaj ich operacjonalizacji. Poniżej prezentujemy strukturę kompetencji społeczno-moralnych z ich szczegółowymi definicjami.

\section{Kompetencje poznawczo-moralne}

Moralna orientacja w świecie - oznacza rozeznanie $\mathrm{w}$ dominujących $\mathrm{w}$ społeczeństwie normach i wartościach na podstawie codziennych doświadczeń oraz obcowania z innymi, jak i dostrzegania napięć między etyką, prawem, polityką ${ }^{15}$.

Orientacja we własnych ideałach etycznych - oznacza samowiedzę na temat własnych preferowanych wartości, potencjalnych konfliktów na styku różnych uznawanych wartości.

Korygowanie znieksztatconego obrazu innych (redukowanie pluralistycznej ignorancji) - oznacza kontrolę poznawczą nad błędami percepcyjnymi występującymi w spostrzeganiu innych.

Rekonstrukcja własnych uczuć moralnych, rozumienie uczuć moralnych innych ludzi - oznacza świadomość własnych stanów emocjonalnych w konfrontacji z sytuacjami o charakterze moralnym oraz rozeznanie i trafne spostrzeganie sytuacji społecznych w odniesieniu do potrzeb, oczekiwań oraz interesów innych ludzi bazujące na empatii i decentracji interpersonalnej.

Rozumienie wielorakich perspektyw moralnych - oznacza orientację w zasadach, jakie wynikają z różnych światopoglądów (chrześcijaństwo, liberalizm, indywidualizm).

14 Por. D. Stępkowski, Szkoła miejscem kształtowania kompetencji moralno-etycznej i kompetencji religijnej, Pedagogia Christiana, 2015, 1, 35, s. 224.

15 Por. Benner, Nokolova za: tamże, s. 226. 


\section{Kompetencje sądzenia moralnego}

Etyczna wrażliwość - oznacza zdolność dostrzegania mających moralne znaczenie sytuacji, relacji, doświadczeń; patrzenie na świat przez pryzmat wartości moralnych ${ }^{16}$.

Krytyczna analiza cudzego i własnego działania - oznacza zdolność do merytorycznej analizy zachowań moralnych własnych i innych ludzi, uwzględniającej kontekst działania i kryteria wynikające z różnych ideałów moralnych.

Analiza i ocena własnej motywacji do zachowań pomocowych - oznacza znajomość pobudek własnych działań altruistycznych, pomocnych, kooperacyjnych, prospołecznych, takich jak np. chęć redukcji własnego pobudzenia wywołanego cierpieniem ofiary, redukcja pobudzenia empatycznego poprzez poprawienie stanu ofiary, uleganie normom społecznym, poddanie analizie zysków i kosztów związanych z działaniem pomocowym ${ }^{17}$.

Kompetencje do wydawania osądów w zgodzie $z$ wtasnymi zasadami i ideatami moralnymi - oznacza zdolność do podawania w wątpliwość i uzasadniania własnych ocen moralnych ze względu na przyjęte kryteria.

\section{Kompetencje projektowania działania moralnego}

Podejmowanie uzasadnionych moralnie decyzji - oznacza zdolność do rozpoznania i analizy problemu ze względu na dobro moralne (własne i cudze), wypracowania wariantów decyzyjnych oraz ustalenia kryteriów ich oceny (wyznaczenie decyzji dopuszczalnych, wystarczających lub optymalnych) i na tej podstawie wybór najlepszego wariantu.

Projektowanie dziatań moralnych w sytuacji konfliktu interesów - oznacza umiejętność koordynowania potrzeb i wymagań wszystkich zaangażowanych stron (podmiotu, innych osób, społeczeństwa).

Wdrożenie i kontrola rezultatów decyzji moralnych - oznacza postępowanie zgodne z planem działania wynikającego z przyjętej zasady etycznej i dokonywanie bieżącej autokorekty zachowania.

Samodoskonalenie moralne - oznacza podejmowanie przemyślanej pracy nad własnym charakterem, motywowane spostrzeganiem rozbieżności między ja realne i ja idealne.

16 Por. N. Szutta, Wychowanie moralne, s. 117.

17 J. Reykowski, Motywacja, postawy prospołeczne a osobowość, Warszawa 1986, s. 27; B. Wojciszke, Człowiek wśród ludzi. Zarys psychologii społecznej, Warszawa 2004. 
Zaprezentowane ujęcie kompetencji moralnych wskazuje na traktowanie ich jako podstawy odpowiedzialnych, autonomicznych i dojrzałych zachowań moralnych. Jeśli uznać te kompetencje za efekt edukacji moralnej, to widać wyraźnie, że edukacja moralna nie jest tożsama z takimi procesami, jak trening, instruowanie, czy indoktrynacja. Nie jest także przekazywaniem wiedzy czy dzieleniem się umiejętnościami. Nie służy też do skłaniania uczniów do zachowywania się $\mathrm{w}$ określony sposób. W zaproponowanym ujęciu celem edukacji moralnej jest promowanie osobistej autonomii. A to oznacza, że jednostka ma świadomość istnienia wielorakich perspektyw etycznych, zbudowała własny system wartości, kieruje się nimi w życiu, bierze odpowiedzialność za własne decyzje moralne, wynikające $\mathrm{z}$ jej wolnych i racjonalnych wyborów.

\section{Analiza porównawcza modeli edukacji moralnej ze względu na kompetencje społeczno-moralne}

\section{Modele edukacji moralnej a kompetencje poznawczo-moralne}

Model klaryfikacji wartości poprzez stymulowanie wglądu we własne preferencje wartościujące jest nastawiony na wspieranie kompetencji poznawczo-moralnych $\mathrm{w}$ obszarze uświadomienia sobie własnych ideałów moralnych. Ponadto, pośrednio, jest zdolny do stymulowania moralnej orientacji w świecie, ponieważ procesy klaryfikacji własnych wartości odbywają się poprzez dyskusje na temat wartości obecnych $\mathrm{w}$ otoczeniu uczniów i uczennic, oceny zachowania się innych oraz zestawianie własnych wartości z alternatywami. Nie jest pewne czy ta dwupoziomowa orientacja w systemach wartości może przełożyć się na korygowanie zasady pluralistycznej ignorancji. Istnieje takie domniemanie, gdyż model ten kładzie nacisk na doświadczanie wartościowania jako procesu. A ponieważ w procesie wartościowania zaangażowane są nie tylko sądy wartościujące, ale także towarzyszące im emocje, należy się spodziewać także stymulowania rozumienia własnych uczuć moralnych, rozpoznawania uczuć innych, a także uwzględniania różnic perspektyw moralnych. Ta ostatnia kompetencja może się pojawiać, jeśli ćwiczenia procesów wartościowania odbywałyby się interakcyjnie. Przemawiają za tym podstawy teoretyczne wskazujące na konflikty moralne w polu ego i superego, stymulowane jednak zewnętrznie.

Podczas gdy model klaryfikowania wartości wychodzi od orientacji we własnych ideałach moralnych, model rozumowania moralnego raczej do niej 
dochodzi, ponieważ główny nacisk kładzie na rozwiązywanie dylematów moralnych. Bez wątpienia, próby ich rozwiązania wymagają odwołania się do własnych preferencji moralnych, ale także zetknięcia $\mathrm{z}$ ujęciami alternatywnymi, obecnymi w środowisku uczniów i uczennic. Konieczność przedstawiania argumentów na rzecz proponowanego rozwiązania i kontrastowanie ich z argumentami innych, powinna sprzyjać kompetencji uwzględniania w myśleniu moralnym alternatywnych perspektyw. Czy to jednak wystarczy, by pokonywać tendencję do zniekształcania obrazu moralności innych? Trudno jednoznacznie powiedzieć, choć trzeba uwzględnić, że wprawki w poszukiwaniu rozwiązania dylematu moralnego sprzyjają ustosunkowywaniu się do wartościowania prowadzonego przez innych. W omawianym modelu nie ma jednak bezpośrednich odniesień do rekonstruowania własnych uczuć moralnych i rozumienia uczuć innych ludzi. Z drugiej strony wartości niemal automatycznie wywołują emocje, a wikłanie się $\mathrm{w}$ ich konflikty budzi uczucia moralne. Ponadto, poznawcza sfera funkcjonowania człowieka nie jest oderwana od uczuciowej. O tym, że model stymulowania rozumowania moralnego jest $\mathrm{w}$ stanie wpływać na wzorce afektywne wiemy więc $z$ ogólnych teorii poznawczych, jednak nie musi to oznaczać, że stymuluje kompetencje związane z rekonstruowaniem własnych uczuć moralnych i rozumieniem uczuć innych. Podobnie ten sam problem można interpretować w odniesieniu do kształtowania charakteru.

W modelu kształtowania charakteru prawdopodobieństwo kształtowania kompetencji związanych z uczuciami moralnymi spada z powodu nawykowego podejścia do internalizacji wartości. Model ten skupia się na transmitowaniu określonej, uznanej za obowiązującą puli wartości, więc nie ma pewności czy daje to orientację dzieciom w świecie wartości w ogóle, czy tylko $\mathrm{w}$ jakiejś jego wersji. Ponieważ jest nastawiony na transmisję, nie ułatwia także orientacji we własnych ideałach moralnych. Oczywiście, nie można wykluczyć, że „przejmowanie wartości” nie koresponduje z myśleniem o nich także $\mathrm{w}$ kategoriach osobistych preferencji, jednak $\mathrm{w}$ żadnej odmianie tego modelu nie można znaleźć deklaracji, iż stymuluje samoświadomość etyczną. Bez wątpienia jednak, internalizacja wartości oznacza budowanie ich systemu, co wydaje się pożądane w fazie konformizmu moralnego. Jednak budowanie systemu wartości z perspektywy „zewnętrznej”, jako systemu wartości nadanych, nie jest tym samym, co można osiągnąć w modelu klaryfikacji wartości. Być może model klaryfikacji zbyt słabo koncentruje się na wartościach społecznych, ale model kształtowania charakteru robi to $\mathrm{z}$ kolei zbyt silnie. Dlatego, nie wydaje się by stymulował, czy jak chcą jego zwolennicy, „kształtował” kompetencje orientacji we własnych ( $z$ naciskiem na własne) ideałach moralnych. Biorąc pod uwagę, że model 
ten opiera się na transmitowaniu wartości, należy mieć wątpliwość, czy jest $\mathrm{w}$ stanie stymulować rozumienie wielorakich perspektyw moralnych. Ta kompetencja wydaje się być poza jego zasięgiem, ponieważ transmisja oznacza przekazywanie jednego systemu wartości, nie zaś wielu zróżnicowanych perspektyw moralnych. Jeśli chodzi natomiast o wzbudzanie kompetencji unikania zniekształcania obrazu innych, model kształtowania charakteru jest bezradny, ponieważ, jak pisano w poprzedniej części, pokazywanie wartości, bez uczenia działania moralnego, tego efektu nie może zatrzymać. Przekonanie o wierności jakiejś wartości niemal automatycznie generuje mechanizm "pluralistycznej ignorancji”.

Inaczej w świetle analizowanych kryteriów przedstawia się model społeczności sprawiedliwościowej. Poprzez codzienne stymulowanie działania moralnego wzbudza wielostronne odniesienia etyczne, konfrontuje ze sobą systemy wartości, zmusza uczniów do codziennego generowania własnego stanowiska aksjologicznego $\mathrm{w}$ wielu kwestiach. Tak więc, kompetencje orientacji w świecie wartości oraz we własnych ideałach etycznych mogą kształtować się jako efekt uczestniczenia uczniów i uczennic w interakcjach o zabarwieniu moralnym. Powołując się także na związek procesów poznawczych z uczuciami, ale przede wszystkim wskazując, że wspólnota sprawiedliwościowa wymaga od jej uczestników systematycznego odnoszenia się do zachowania i oczekiwań moralnych innych, można przyjąć, że model ten rozwija kompetencje uczuciowe: rekonstrukcję własnych uczuć i rozumienie uczuć innych. Dzieje się to raczej w drugim planie, w trakcie codziennych interakcji. Właśnie interakcyjny charakter oddziaływań edukacyjnych jest także potencjalnie $\mathrm{w}$ stanie redukować nietrafne sądy na temat moralności innych. Chodzi o okazje do ich weryfikowania w zetknięciu z rzeczywistą sytuacją. Ta kwestia nie jest jednak wyraźnie wyodrębniona jako potencjalny efekt edukacyjny w omawianym modelu. Dlatego trudno jednoznacznie ją rozstrzygnąć, zwłaszcza że nie jest pewne czy taka sytuacyjna weryfikacja (sądziłem, że mi nie pomoże, a pomógł) jest warunkiem wystarczającym do skutecznego korygowania efektu "pluralistycznej ignorancji". I na koniec pozostaje kwestia rozumienia wielorakich perspektyw moralnych. Przy założeniu, że wspólnota sprawiedliwościowa dostarcza odmiennych perspektyw moralnych, należy uznać, że omawiany model ma szansę na skuteczne stymulowanie tej kompetencji.

\section{Modele edukacji moralnej a kompetencje sądzenia moralnego}

Klaryfikowanie wartości jest procesem wybierania, oceniania i działania moralnego. Poprzez wybieranie wartości oraz ocenianie stymuluje się zdol- 
ność dostrzegania sytuacji moralnych, rozpatrywania świata z różnych perspektyw. Zanim nastąpi wybór wartości, proces klaryfikacji stawia także jego uczestników przed zadaniem dokonania krytycznej analizy działania potencjalnie wynikającego $\mathrm{z}$ analizowanych wartości. A to sprawia, że uczniowie i uczennice rozpatrują różne kryteria oceny sytuacji, wynikające z różnych ideałów moralnych. Czy model klaryfikacji wartości pobudza do analizy własnej motywacji działania moralnego? Prawdopodobnie tak, ponieważ proces klaryfikacji obejmuje także działanie wynikające z wybranych wartości, a samoocena motywacji do działania moralnego powinna pojawiać się także na etapie oceny możliwości sprostania realizowaniu danej wartości. Analizując stosowane $\mathrm{w}$ tym modelu techniki wychowawcze, można także pozytywnie postrzegać możliwość rozwijania osądów moralnych, zwłaszcza w konfrontacji $\mathrm{z}$ klaryfikowanymi własnymi ideałami, kiedy trudno uniknąć podawania $\mathrm{w}$ wątpliwość własnych ocen moralnych ze względu na przyjęte uprzednio kryteria.

Podobny potencjał rozwijania kompetencji sądzenia ma model stymulowania rozumowania moralnego, szczególnie czuły na kompetencję do wydawania sądów. Jest ona częścią podejmowania prób rozwiązywania dylematów moralnych oraz szukania dla tych rozwiązań argumentów. Można jednak mieć wątpliwość co do nieograniczonych możliwości krytycznej analizy własnego i cudzego działania. Być może w trakcie ćwiczeń w rozumowaniu moralnym następuje merytoryczna analiza zachowań moralnych, jednak nie jest to mocny punkt tego modelu, który bardziej odwołuje się do myślenia, niż do działania. Rozwiązanie dylematu nie musi zawsze oznaczać rozpatrywania go w kontekście konkretnego działania. Podobne wątpliwości można mieć w odniesieniu do autoanalizy motywacji do zachowań pomocowych. Efekt ten może następować, jeśli rozumowanie w swych argumentach merytorycznych angażuje myślenie o własnym altruizmie, działaniach prospołecznych, czy kooperacyjnych. Nie wydaje się jednak to mocną stroną analizowanego modelu. Zwłaszcza że uczniowie rozwiązują dylematy często abstrakcyjne, o niskim związku z ich codziennością i ewentualnym działaniem moralnym. Dylematu Heinza nie można tak łatwo przenieść do sfery działania.

Modele kształtowania charakteru mogą z kolei nie być oderwane od działania moralnego, ponieważ jednym z warunków ich skutecznego stosowania jest dostarczanie uczniom doświadczeń moralnych, takich jak zaangażowanie $\mathrm{w}$ sprawy społeczne, praca $\mathrm{w}$ domach opieki itp. Dlatego, etyczna wrażliwość oraz analiza własnej motywacji działania pomocowego należą do kompetencji, które mogą być kształtowane w tym modelu. Nieco inaczej można interpretować krytyczną analizę własnego i cudzego działa- 
nia moralnego, która współwystępuje już z orientacją we własnych ideałach, $\mathrm{z}$ doświadczaniem wielorakich perspektyw moralnych. Model transmisyjny jest - niestety - zrelatywizowany do jednego tylko systemu wartości i często skonfliktowanego $\mathrm{z}$ innymi. Największy problem modelu kształtowania charakteru można łączyć z kryterium, jakim są kompetencje wydania osądów zgodnych $\mathrm{z}$ własnymi ideałami moralnymi. I problem ten nie dotyczy, wbrew pozorom, jedynie faktu, że wychowankowie nie budują własnego systemu wartości, a przejmują narzucony w transmisji edukacyjnej. Choć to też kwestia warta dyskusji. Głównie chodzi jednak o brak kryteriów do krytycznej analizy zjawisk moralnych, $\mathrm{w}$ tym podawania $\mathrm{w}$ wątpliwość własnych ocen moralnych. Podanie ich w wątpliwość oznaczałoby podanie w wątpliwość społecznego systemu wartości, który jest transmitowany. Można powiedzieć, że to patowa sytuacja z perspektywy kompetencji wydawania sądów moralnych.

Problemy te nie dotyczą natomiast modelu społeczności sprawiedliwościowej. Wydawanie osądów moralnych i bronienie perspektyw, z których te osądy są formułowane, stanowi przedmiot codziennych doświadczeń stymulowanych przez ten model. Spotkania społeczności uczniów i uczennic pozwalają właśnie na kwestionowanie i uzasadnienie własnych ocen moralnych ze względu na kryteria regulujące dany dyskurs moralny. Podobnie jest z wrażliwością etyczną, którą stymuluje codzienne rozwiązywanie wielu kwestii moralnych, takich jak agresja, prześladowanie, oszustwa. Dodatkowo, ponieważ postanowienia społeczności moralnej są wprowadzane w życie przez jej uczestników, mają oni okazję do analizowania pobudek własnych działań etycznych, związanych $\mathrm{z}$ altruizmem, pomocowych, kooperacyjnych i innych. Wydaje się, że dobre dopasowanie tego modelu do omawianych kompetencji wynika właśnie z jego aktywnego charakteru, z faktu, że uczniowie i uczennice mogą brać odpowiedzialność za własne działania, umocowane $\mathrm{w}$ wartościach podzielanych przez społeczność. A ponieważ te wartości są wynegocjowane i mogą podlegać zmianom, wystawiają wychowanków na różne perspektywy moralne, co wymaga ciągłej decentracji.

\section{Modele szkolnej edukacji moralnej a kompetencje projektowania działania moralnego}

Odkrywanie własnych wartości w modelu klaryfikacji łączy się z dyskusjami na temat wartości, z rozwiązywaniem dylematów moralnych, podczas których uczniowie i uczennice opisują swoje zachowanie w analizowanych 
sytuacjach moralnych oraz dyskutują alternatywne rozwiązania. Taki tryb pracy wychowawczej rozwija kompetencje związane z podejmowaniem decyzji moralnych oraz ich uzasadnianiem, a także sprzyja ćwiczeniu projektowania działań moralnych, w tym - być może - w sytuacji konfliktu interesów. Wyrażona wątpliwość bierze się stąd, że potencjalnie ten system oddziaływań może obejmować konflikty interesów, jednak brakuje pewności, ponieważ koncentracja na własnych wartościach niekoniecznie musi się wiązać z ćwiczeniem umiejętności koordynowania potrzeb wszystkich stron konfliktu. Podobnie niezupełnie jasne wydaje się, czy proces klaryfikacji wartości obejmuje także wdrażanie i kontrolę rezultatów decyzji moralnych, co wiąże się już z autoanalizą postępowania zgodnego z przyjętą wartością oraz z autokorektą zachowania. Akurat brakuje w literaturze danych odsłaniających dokładnie metodykę realizowania ostatniego etapu procesu klaryfikacji wartości - działania. Natomiast nie ulega wątpliwości, że omawiany model jest czuły na stymulowanie kompetencji samodoskonalenia moralnego poprzez przyglądanie się rozbieżności między ja realnym a idealnym. Jest to właśnie sedno uświadamiania sobie własnych preferencji etycznych. Ten efekt rozwojowy z kolei nie jest szczególnie eksponowany przez model rozumowania moralnego. Zapewne ćwiczenia w rozwiązywaniu dylematów moralnych wpływają także na samodoskonalenie moralne, jednak nie ma w tym modelu mowy o systematycznym oddziaływaniu tego rodzaju. $\mathrm{Z}$ kolei, podejmowanie decyzji moralnych i ich uzasadnianie jest kompetencją, na której rozwijanie model rozumowania moralnego jest nastawiony. Podobnie zresztą jest z projektowaniem działań moralnych, ponieważ decyzja wraz z argumentami za i przeciw opiera się na uprzedniej analizie potrzeb i oczekiwań stron konfliktu moralnego. No i na koniec warto podkreślić, że omawiany model nie przewidując pracy nad realizacją decyzji moralnych, nie ma szczególnie okazji do stymulowania zgodności postępowania $\mathrm{z}$ wartościami, z których działanie zostało wywiedzione.

Zwolennicy modelu kształtowania charakteru piszą o pięciu warunkach, które muszą spełnić wychowawcy, aby model działał. Są to: operowanie przykładem, posługiwanie się wyjaśnieniami, perswazja, kreowanie środowiska moralnego oraz dostarczanie uczniom doświadczeń moralnych. Nie wydaje się, by którakolwiek z tych metod oddziaływania stwarzała możliwość podejmowania decyzji moralnych opartych na uzasadnieniach, wybierania ich najlepszych wariantów ze względu na różne kryteria. Nawet „dostarczanie doświadczeń moralnych", z powodu swego dyrektywnego charakteru (dostarczanie), nie stwarza warunków do wolnego wypracowywania alternatywnych wariantów decyzji oraz ustalania kryteriów ich oceny. Dodatkowo działa tu zasada zamknięcia modelu na wielorakie perspektywy aksjolo- 
giczne, o czym pisano wcześniej. Podobnie, nawet jeśli można stworzyć warunki do projektowania działań moralnych w ramach np. „kreowania środowiska moralnego", to projektowanie ich w sytuacji konfliktu interesu jest utrudnione, ponieważ koordynowanie potrzeb i wartości wszystkich zaangażowanych $\mathrm{w}$ konflikt stron wydaje się mało prawdopodobne $\mathrm{w}$ warunkach braku otwartości na alternatywne systemy wartości. Natomiast, kompetencja działania zgodnego $\mathrm{z}$ planem wynikającym $\mathrm{z}$ przyjętej zasady etycznej jest rozwijana przez omawiany model, co opisane metody wychowawcze mogą w pewnym stopniu zapewnić. Podobnie model kształtowania charakteru przewiduje systematyczne działania nastawione na samodoskonalenie $\mathrm{w}$ zakresie różnych operacji na cnotach moralnych. Czy jednak będzie to wgląd w ja realne? Model kształtowania charakteru wydaje się być częściowo zablokowany na pełne rozwijanie kompetencji projektowania działania moralnego na poziomie dążenia do autonomii moralnej. Jest tak za sprawą transmisyjnego stylu wychowania oraz nastawienia na uznany na właściwy system wartości, w którym inne wartości - alternatywne nie mogą się zmieścić. Uczniowie i uczennice nie mają okazji skonfrontowania własnych wartości, nieuznawanych przez społeczeństwo, z wartościami nadawanymi. Zwolennicy modelu kształtowania charakteru piszą o kognitywno-afektywnym ujęciu cnoty, który ich zdaniem ${ }^{18}$ odpowiada za wiedzę o dobru, rozpoznawanie sytuacji moralnych, właściwe stosowanie zasad moralnych oraz motywację do właściwego zachowania moralnego. Być może taką konstrukcję teoretyczną można zbudować, jednak jej pedagogiczna operacjonalizacja wydaje się niemożliwa na poziomie działań instruktażowo-perswazyjnych.

W innej sytuacji jest model wspólnoty sprawiedliwościowej, który wydaje się być zbudowany jako pomost między wartościami a działaniem z nich wynikającym. Trening $\mathrm{w}$ podejmowaniu decyzji moralnych stanowi codzienność funkcjonowania szkoły jako wspólnoty sprawiedliwościowej, co nie ulega wątpliwości. Jeśli jednak myślimy o projektowaniu działań moralnych w sytuacji konfliktu, to opierając się na nazwie modelu możemy mieć pewne wątpliwości. Chodzi o to, czy w sytuacji konfliktu nie będą preferowane rozwiązania oparte na kryterium sprawiedliwości, co by oznaczało brak otwartości na uwzględnianie potrzeb i oczekiwań ludzi patrzących na problem z innej perspektywy etycznej. Omawiany model został jednak zmodyfikowany na podstawie krytycznych uwag C. Gilligan w odniesieniu do jednostronności etyki sprawiedliwości. Po uwzględnieniu zasad wynikających z etyki troski nastąpiło otwarcie także na konteksty wspólnotowe, więc wydaje się, że powyższe zastrzeżenie nie jest już trafne. Wdrażanie

${ }^{18}$ N. Szutta, Wychowanie moralne, s. 113. 
i kontrola decyzji moralnych w podejściu tym - najbardziej ze wszystkich analizowanych nastawionym na działanie - nie budzi wątpliwości. Zwłaszcza że postępowanie zgodne z przyjętymi wartościami jest przez samą społeczność szkoły kontrolowane, co sprzyja autokorekcie zachowania osób w nie zaangażowanych. Wspólnotowość jest także dodatkowym czynnikiem stymulującym samodoskonalenie moralne uczniów i uczennic, ponieważ moralna kultura szkoły znajduje się w ciągłym procesie transformacji, a więc także jej twórcy i uczestnicy.

Podsumowując przeprowadzoną analizę, można zaważyć, że nie zawsze udawało się precyzyjnie oszacować czy dany model spełnia kryterium danej kompetencji. Takie są jednak realia analizy teoretycznej. Niektóre kwestie związane z dopasowaniem modelu do kryterium można wydedukować na podstawie wiedzy ogólnej.

Tabela 1

Modele edukacji a kompetencje społeczno-moralne

\begin{tabular}{|l|l|l|l|l|}
\hline & $\begin{array}{c}\text { Klaryfikacja } \\
\text { wartości }\end{array}$ & $\begin{array}{c}\text { Stymulowanie } \\
\text { rozumowania } \\
\text { moralnego }\end{array}$ & $\begin{array}{c}\text { Kształcenie } \\
\text { charakteru }\end{array}$ & $\begin{array}{c}\text { Wspólnota } \\
\text { sprawiedliwościowa }\end{array}$ \\
\hline $\begin{array}{l}\text { Kompetencje po- } \\
\text { znawczo-moralne }\end{array}$ & & & & \\
\hline $\begin{array}{l}\text { Moralna orientacja } \\
\text { w świecie }\end{array}$ & & & & \\
\hline $\begin{array}{l}\text { Orientacja we } \\
\text { własnych ideałach } \\
\text { etycznych }\end{array}$ & & & \\
\hline $\begin{array}{l}\text { Korygowanie znie- } \\
\text { kształconego obra- } \\
\text { zu innych }\end{array}$ & & & \\
\hline $\begin{array}{l}\text { Rekonstrukcja } \\
\text { własnych uczuć } \\
\text { moralnych, rozu- } \\
\text { mienie uczuć mo- } \\
\text { ralnych innych }\end{array}$ & & & & \\
\hline $\begin{array}{l}\text { Rozumienie wielo- } \\
\text { rakich perspektyw } \\
\text { moralnych }\end{array}$ & & & & \\
\hline $\begin{array}{l}\text { Kompetencje są- } \\
\text { dzenia moralnego }\end{array}$ & & & & \\
\hline $\begin{array}{l}\text { Etyczna wrażli- } \\
\text { wość }\end{array}$ & & & & \\
\hline $\begin{array}{l}\text { Krytyczna analiza } \\
\text { cudzego i własne- } \\
\text { go działania }\end{array}$ & & & & \\
\hline
\end{tabular}




\begin{tabular}{|l|l|l|l|l|}
\hline $\begin{array}{l}\text { Analiza i ocena } \\
\text { wo zachoj motywacji } \\
\text { mocowych po- }\end{array}$ & $\begin{array}{c}\text { Klaryfikacja } \\
\text { wartości }\end{array}$ & $\begin{array}{c}\text { Stymulowanie } \\
\text { rozumowania } \\
\text { moralnego }\end{array}$ & $\begin{array}{c}\text { Kształcenie } \\
\text { charakteru }\end{array}$ & $\begin{array}{c}\text { Wspólnota } \\
\text { sprawiedliwościowa }\end{array}$ \\
\hline $\begin{array}{l}\text { Kompetencje do } \\
\text { wydawania osą- } \\
\text { dów w zgodzie } \\
\text { z własnymi zasa- } \\
\text { dami i ideałami } \\
\text { moralnymi }\end{array}$ & & & & \\
\hline $\begin{array}{l}\text { Kompetencje pro- } \\
\text { jektowania dzia- } \\
\text { lania moralnego }\end{array}$ & & & & \\
\hline $\begin{array}{l}\text { Podejmowanie } \\
\text { uzasadnionych } \\
\text { moralnie decyzji }\end{array}$ & & & & \\
\hline $\begin{array}{l}\text { Projektowanie } \\
\text { działań moralnych } \\
\text { w sytuacji konflik- } \\
\text { tu interesów }\end{array}$ & & & & \\
\hline $\begin{array}{l}\text { Wdrożenie i kon- } \\
\text { trola rezultatów } \\
\text { decyzji moralnych }\end{array}$ & & & & \\
\hline $\begin{array}{l}\text { Samodoskonalenie } \\
\text { moralne }\end{array}$ & & & & \\
\hline
\end{tabular}

nie spełnia kryterium może spełniać, ale nie musi

spełnia kryterium

Źródło: analizy własne.

Jednak w sytuacji, kiedy model do nich nie odnosi się bezpośrednio, trudno o jednoznaczne rozstrzygnięcie. $W$ takich momentach pisano, że model $\mathrm{w}$ pewnych okolicznościach może potencjalnie spełnić kryterium, ale zdecydowanie powiedzieć tego nie można. W tabeli 1 oznaczono to polem „może spełniać, ale nie musi”. Często jednak nie było jasne, czy model spełnia kryterium czy nie. Taką sytuację oznaczano odpowiednio odcieniami „spełnia kryterium” i „nie spełnia kryterium”. Rozpatrując tabelę 1, dowiadujemy się, że model wspólnoty sprawiedliwościowej spełnił analizowane kryteria w stopniu największym, następnie model klaryfikacji wartości, a najwięcej wątpliwości pojawiło się, odpowiednio, w odniesieniu do modelu kształtowania charakteru i stymulowania rozumowania moralnego. 
Pierwsze dwa modele okazały się bardziej wielostronne i operacyjne w sensie pedagogicznym niż modele pozostałe. Nasza analiza ma status hipotezy, wniosku z danych teoretycznych, które warto, jak sądzimy, poddać też analizie empirycznej.

\section{BIBLIOGRAFIA}

Arthur J., Traditional approaches to character education in Britain and America, [w:[ Handbook of moral and character education, red. L.P. Nucci, D. Narvaez, Routledge, New York 2008.

De Waal F., Matpy i filozofowie, przekł. B. Brożek, M. Furman, Copernicus Center Press, Kraków 2013.

http://eguilibrio.blogi.com/czy-potrzebna-jest -nam-edukacja-moralna/9.08.2016

Kaplan P.S., Educational psychology for tomorrow's teacher, West Publishing Company, St. Paul - New York - Los Angeles - San Francisco 1990.

Konarzewski K., Pedagogika celów czy pedagogika wartości? Kwartalnik Pedagogiczny, 2013, 2. Lind G., Edukacja moralna. Teoria dwuaspektowa, Principia, 2013, LVII-LVIII.

Nucci L.P., Narvaez D., Introduction and overview, [w:] Handbook of moral and character education, red. L.P. Nucci, D. Narvaez, Routledge, New York 2008.

Power F.C., Higgins-D`Alessandro A., The just community approach to moral education and the moral atmosphere of the school, [w:] Handbook of moral and character education, red. L.P. Nucci, D. Narvaez, Routledge, New York 2008.

Reykowski J., Motywacja, postawy prospoteczne a osobowość, PWN, Warszawa 1986.

Simon S.B., Havley R.C., Britton D.D., Krystalizacja wartości. Ćwiczenia pisemne dla rozwoju osobowego, Wydawnictwo Edytor, Torun - Poznań 1992.

Stępkowski D., Szkota miejscem kształtowania kompetencji moralno-etycznej i kompetencji religijnej, Pedagogia Christiana, 2015, 1, 35.

Szutta N., Wychowanie moralne z perspektywy etyki cnót, Diametros, 2015, 46.

Wojciszke B., Człowiek wśród ludzi. Zarys psychologii społecznej, Wydawnictwo Naukowe Scholar, Warszawa 2004. 